\title{
Controlled Release Liquid Dosage Form
}

National Cancer Institute

\section{Source}

National Cancer Institute. Controlled Release Liquid Dosage Form. NCI Thesaurus. Code C69026.

A solution or suspension designed to release active and/or inert ing redient(s) at a controlled rate. 